Mitter, Wolfgang

\title{
State - nation - education. An essay to discussing an unsolved educational issue in the European context
}

Hungarian Educational Research Journal 4 (2014) 1, 13 S.

Quellenangabe/ Reference:

Mitter, Wolfgang: State - nation - education. An essay to discussing an unsolved educational issue in the European context - In: Hungarian Educational Research Journal 4 (2014) 1, 13 S. - URN: urn:nbn:de:0111-pedocs-99136 - DOI: 10.25656/01:9913

https://nbn-resolving.org/urn:nbn:de:0111-pedocs-99136

https://doi.org/10.25656/01:9913

\section{Nutzungsbedingungen}

Gewährt wird ein nicht exklusives, nicht übertragbares, persönliches und beschränktes Recht auf Nutzung dieses Dokuments. Dieses Dokument ist ausschließlich für den persönlichen, nicht-kommerziellen Gebrauch bestimmt. Die Nutzung stellt keine Übertragung des Eigentumsrechts an diesem Dokument dar und gilt vorbehaltlich der folgenden Einschränkungen Auf sämtlichen Kopien dieses Dokuments müssen alle Urheberrechtshinweise und sonstigen Hinweise auf gesetzlichen Schutz beibehalten werden. Sie dürfen dieses Dokument nicht in irgendeiner Weise abändern, noch dürfen Sie dieses Dokument für öffentliche oder kommerzielle Zwecke vervielfältigen, öffentlich ausstellen, aufführen, vertreiben oder anderweitig nutzen.

Mit der Verwendung dieses Dokuments erkennen Sie die Nutzungsbedingungen an.

\section{Terms of use}

We grant a non-exclusive, non-transferable, individual and limited right to using this document.

This document is solely intended for your personal, non-commercial use. Use of this document does not include any transfer of property rights and it is conditional to the following limitations: All of the copies of this documents must retain all copyright information and other information regarding legal protection. You are not allowed to alter this document in any way, to copy it for public or commercial purposes, to exhibit the document in public, to perform, distribute or otherwise use the document in public.

By using this particular document, you accept the above-stated conditions of use.

\section{Kontakt / Contact:}

\section{peDOcs}

DIPF | Leibniz-Institut für Bildungsforschung und Bildungsinformation Informationszentrum (IZ) Bildung

E-Mail:pedocs@dipf.de

Internet: www.pedocs.de

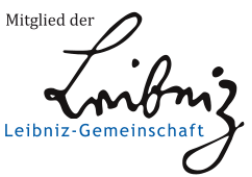




\title{
WOLfGang MitTeR
}

\section{StATE - NATION - EDUCATION. AN ESSAY TO DisCUSSING AN UNSOLVED EDUCATIONAL ISSUE IN THE EUROPEAN CONTEXT}

\begin{abstract}
A bstract This essay is focused on a critical approach to the concept of a nation state which has been built on the exclusive domination of one ethnic group and on one 'national language'. This concept which traces back to the emergence of the 'nation state' in the $18^{\text {th }}$ century and is illustrated by a few historical examples has proved, in most cases, not to be based on real facts, but rather on the ideological concept of a narrow nationalism. Consequently, this analysis ends up with the plea for the state as a community to be built on the acknowledgment of multiple identities and multilingualism.
\end{abstract}

\section{Educational Sovereignty in the Modern Nation State}

Education systems of today are products of the modern nation state, as it emerged in the French Revolution and was institutionalized by Napoleon in France. According to this basic remark it is open whether the state exercises its competencies immediately, through centralized agencies, or delegates it to decentralized 'school providers' at the regional or local level. The same is true with regard to its basic administrative structure as centralized or federal unit, the latter consisting of 'federal states' which exercise the function of the federation partly or totally. The latter form is clearly exemplified by Germany and Switzerland. Hence by education system we understand a sub-system of the modern state whose history begins with the emergence of the absolute monarchy on the European continent in the $17^{\text {th }}$ century and has continued its existence along with the development of the liberal and democratic form of government until today (cf. Archer, 1984, p. 19; Mitter, 2004, p. 352). The establishment resulted from the rulers' explicit intention "to instruct the subject in the most necessary cultural skills to enable him to read the directions given by the authorities, to make himself understood in the state of civil servants (Beamtenstaat) and, above all, to play his part in the growth of the state's welfare through economic efficacy" (Heckel \& Avenarius, 1986, p. 3 ).

It was the birth of the modern nation in the period of the French Revolution that amalgamated state and nation in the 'modern nation state' and, consequently, in the foundation of 'national education systems' as the dominant pattern of the superordinate category of 'state education system'. In this fundamental configuration it integrated its commitment to the nation state and its constitutive 
Wolfgang Mitter: State - nation - education. An essay to discussing an unsolved educational issue in the European context. Hungarian Educational Research Journal. Volume 4, Issue 1, 2014. doi 10.14413/HERJ2014.02.02

components, namely, national territory, national government and national identity which fulfilled their fundamental function as basic concepts of ideological cohesion and institutional stability. As an educational value this commitment was instrumentalized under the slogan of' 'patriotism' in the instruction process of all public schools. May it suffice to add that in most states legislative and administrative provisions have been made to include the private school sector in the overall framework comprising the educational sovereignty of the modern nation state.

The development of the 'national' component in the individual modern education systems has not been a simultaneous process all over Europe. Of course, certain environmental circumstances, such as number of members, territorial concentration, economic prosperity and, finally, sociocultural standards (e. g. the existence of cultural and political elites) play a significant role. In particular, simultaneousness was delayed by the parallel continuity of trans-national states over the past three centuries with democratic Switzerland as its prominent example or, at least over some periods, with the pre-democratic Hapsburg Empire concurrently and most significantly contributing to the overall development of modern state education (cf. Cowen, 1998, p. 63). In this regard the end of World War I can be considered as a milestone in the successful progress of the national education system in Europe. While the present paper is focused on Europe, it seems important to add that this progress has radiated to the other continents of the globe.

\section{Monolingualism and Multilingualism}

Since the end of World War I the modern nation state has become the dominant form in which the inhabitants of demarcated territories have organized their ways of life in the frameworks of political units. The concept of the French revolutionaries, however, was based upon the illusory assumption that the 'nation' could be built as a community to be held together by a "large-scale solidarity", according to the concept which was expressed by the French sociologist Ernest Renan (cf. Renan 1996, pp. 52-54), though almost one hundred years later, namely in 1882 . This concept, however, has neglected, from its articulation, viability and vitality of ethnicity and, in particular, language as essential ethnical component. This why the 'nation-builders', even in France, have, in principle, underestimated the complexity of their self-chosen task, insofar as they neglected the ethnical and linguistic particularities of ethnic minorities beside the 'state nation'. Moreover, quantitative facts and specific manifestations of political consciousness have always played a constitutive role in the process of nation-building. 
Wolfgang Mitter: State - nation - education. An essay to discussing an unsolved educational issue in the European context. Hungarian Educational Research Journal. Volume 4, Issue 1, 2014. doi 10.14413/HERJ2014.02.02

Present-day multilingualism has emerged as an outcome of modern nation building, but its existence as such is much older, for it has been a vital factor in many European regions from the medieval period onwards and has shaped cohabitation among people in their everyday lives. It became particularly evident at big common gatherings, such as the bustle at markets and fairs, but also in the everyday co-existence. It determined the communication at the micro-level and, moreover, at the macro-level of the political scene. The latter fact can be exemplified by the co-existence between Czechs and Germans in Bohemia and Moravia in the $13^{\text {th }}$ and $14^{\text {th }}$ centuries, above all under the rule of Charles IV and before its collapse by the Hussite Wars. In this context the following comment by the German historian Ferdinand Seibt is worth quoting: "The national linguistic community, for its part, is, in its limitations and particularities, a social product like any other community formation, but it has attained, in the course of our cultural development, above all by the compulsory school attendance, a more reliable cohesion than all the other criteria" (Seibt, 1992, p. 30). The problematic nature, as regards the 'linguistic' component of this definition, will be resumed later.

In this context the educational history of the 'Austrian' half of the Hapsburg Empire in the $19^{\text {th }}$ and early $20^{\text {th }}$ centuries is worth to be paid some attention (cf. Mitter, 2004, p. 353), namely with regard to the handling of the language as instructional medium within the centralized education system. The region-based characteristics consisted in the language as exclusive or, at least, main instruction medium, caused by the bi- or multilingual composition of the local or provincial populations. This specific case can be clearly exemplified by the establishment of' 'local school districts' composed of schools with the same instruction medium, e.g. Czech and German in Bohemia and Moravia. It is true that these 'educational spaces' were only introduced within the school-providing territorial communities, but in 1873 respectively 1905 their ranges of operations were extended to the administrative division of the provincial authorities (Landesschulbeiräte) into linguistically diversified sectors being in charge of schools with regard to syllabi and teacher appointment, but not to budgetary matters (cf. Wandruszka \& Urbanitsch, 1980, p. 1172).

This trend continuing in a few successor states of the Hapsburg Empire after its collapse signalized the first step to the establishment of ethnically diversified administrative units to be discovered today in various organizational arrangements within one territory and in bi-ethnic regions, e.g. Wales in the U. K. or South Tyrol (Alto Adige) in Italy. Their composition of semi-autonomous sectors suggests to 
Wolfgang Mitter: State - nation - education. An essay to discussing an unsolved educational issue in the European context. Hungarian Educational Research Journal. Volume 4, Issue 1, 2014. doi 10.14413/HERJ2014.02.02

classify them as 'national sub-systems' under the remaining constitutional umbrella of their respective 'national' education systems. These examples indicate openings of the preceding wide-spread rigidity of 'national school systems' concerning the monopoly of the official language in administration and jurisdiction as well as the instruction medium in the public school sector of their 'national education systems'. Other states, however, have retained the monopoly of the 'national language' in the political, administrative and educational communication, which has been the representative case in France until today as a constitutive component of her educational sovereignty. In the amendment of article 2 of the French constitution (of 1959), enacted in 1992, this monopoly was confirmed: 'French is the language of the Republic' (cf. Trouillet, 1997, p. 68). The French model as such has been widely diffused all over the European continent (and the rest of the world) and implemented in the respective national education systems, even though such policies have not necessarily entailed the rigid formulation of the French document. Summing up this introductory consideration, education in Europe is far from being unified with regard to the relation between 'nation state' and 'instruction language'.

\section{Nations and Languages}

Advocates of the contemporary nation state like to make references to the transperiodical, if not even 'eternal' existence of nations, regarding them as the most essential structural elements of the global society. In Europe this argumentation, tracing back to the French Revolution ${ }^{1}$ and reaching its climax after World War I, has maintained its dominant position until today, and it has survived the, in the end unsuccessful, attempts to subject nation states to the big totalitarian systems, as materialized by National Socialism in Germany, and Communism in the Soviet Union. Those attempts to extinguish European nation states by violence totally failed. However, the peaceful efforts, starting after World II and extended by the collapse of communism at the end of the eighties, have, so far, also missed their ultimate goal of developing Europe into the genuinely integrated body of a federal state, as the initiators of the European idea had pursued in the fifties and sixties of the $20^{\text {th }}$ century. The nation state has remained as the dominant type of state on the European map, confirmed by national constitutions and legal provisions and only partially restricted by the statutes of the European Union.

Accordingly, the European nation states have, up today, legally asserted their principal educational sovereignty according to the principle of 'subsidiarity', as guaranteed by article $3 \mathrm{~b}$ of the Treaty of Maastricht (1992). This is one side of the coin. The other side says that the process of integration in in the European Union has 
Wolfgang Mitter: State - nation - education. An essay to discussing an unsolved educational issue in the European context. Hungarian Educational Research Journal. Volume 4, Issue 1, 2014. doi 10.14413/HERJ2014.02.02

unleashed new trends not only in the economic (which will not be tackled in the present paper), but also in the educational sector which affect, in the reality of aims and efforts, the ranges of policy-making in various fields. These trends are focused on breaking the monopoly of the modern nation state in various fields of educational governance. In the Treaty of Maastricht whose essentials were confirmed by the Treaty of Amsterdam (1997), the education systems have been explicitly included in the legal responsibilities of the European Union. Furthermore, the Open Method of Co-ordination (OMC), adopted by the Lisbon Summit in 2000 has though gradually widened the EU's competencies by starting a strategy to develop common indicators and benchmarks, aimed at improving the quality of the education systems (Dale \& Robertson, 2002, p. 26).

In principle, the language question has not been affected by these recent policies, but it would be misleading to neglect particular changes in this sector nevertheless. In a good number of countries ethnic minorities have been provided with schools or classes with their vernacular languages as exclusive or at least partial instruction media, in the latter case alongside with the 'national languages', now with the status of 'second' languages. In bi- or multi-ethnic regions, such as Wales (United Kingdom) with Welsh and English and South Tyrol (Alto Adige, Italy) with German, Italian and Ladino, this trend has been extended to the establishment of autonomous 'education sub-systems' with regard to the instruction media to be taught under the supervision of autonomous authorities. This trend points back to the aforementioned initiative which were taken in the last period of the Hapsburg Empire. Moreover, these recent policies join the developments in countries where multilingualism has been traditionally anchored, such as in Switzerland and Belgium whose education systems, however, are especially characterized by the principle of one language each in most of the cantons or districts.

The receivers of multilingualism, in different forms within national education systems, are members of indigenous minorities who have lived in the respective nation states for centuries and sometimes even longer than the today 'state nations'. Therefore the concept of 'nation state' as such is misleading when it is based on the assumption of one nation with one ethnic population and one language, i.e. on the congruence of 'nation state' and 'state nation'. It is true that, looking at Europe in past and present, It is true that, with the exception of Portugal, Iceland and the ministates of Liechtenstein, Andorra, Monaco and San Marino, concept and status of 'nation state' are based upon territory and sovereignty in terms of law and power, 
Wolfgang Mitter: State - nation - education. An essay to discussing an unsolved educational issue in the European context. Hungarian Educational Research Journal. Volume 4, Issue 1, 2014. doi 10.14413/HERJ2014.02.02

but they are void of ethnic and lingual cohesion. The attitudes to 'national identity' within the 'ethnic' or 'national' minorities ${ }^{2}$ can be very different: they can include

(1) loyalty to the 'nation state' and to the dominance of the 'state nation' (e.g. Swedes in Finland, Sorbs in Germany, Germans in Belgium); (2) factual acceptance of the given legal status (e.g. Galicians in Spain, German-Speaking Tyrolians in Italy); (3) latent opposition and demand of self-government within the 'national' framework (e.g. Albanians in Macedonia) or (4) active resistance in non-violent or violent form, as 'ethnic' or 'national' autonomy or even separation in form of national independence or unification with the linguistic 'mother land' (Catalans in Spain, Scots in the U.K., Serbs in Bosnia-Herzegovina).

The previous and current European history, therefore, gives insight into all these versions. Opposition and resistance are, as a rule, responses to demands raised by the majority population to monopolize the status of 'state nation' and to ignore opposite arguments. It seems that in the everyday life as well as at the level of policy-making these complexities of 'nation state' and 'state nation' are often concealed, no matter whether such concealment is based on indifference or intention. The national education systems mirror this diversity with regard to administrative structures, curricula and the organization of schools and classrooms according to the pupils' linguistic and cultural backgrounds. The highest stage of harmonization is achieved, when the contentment of the minorities (and also of the 'state nation') is in agreement with the all-accepted national identity.

\section{Migration - a New Challenge}

In modern times cohesion of nation states, as far as they are not monocultural in terms of language and ethnicity, has been based on conciliatoriness of 'state nation' and indigenous minorities. However, the concept of indigenous minorities has always contained a certain degree of vagueness, insofar as the length of residence is concerned. To how many years (or centuries) of ancestry have you to go back to be acknowledged as the member of an 'indigenous' group? This issue has become more and more relevant in recent years, insofar as the importance of this question has increased with the regard of 'new' migration and immigration. To look for an earlier example in modern times, one my look back to the Huguenots' arrival in a good number of German principalities in the $17^{\text {th }}$ and $18^{\text {th }}$ centuries. They preserved their cultural heritage (including the French language) until the $20^{\text {th }}$ century Parallel policies can be made out in the history of the Hapsburg Empire, namely in the colonization of the deserted region to the north of the Danube with Hungarians, Serbs and Germans in the beginning of the $18^{\text {th }}$ century - as a result of the successful 
Wolfgang Mitter: State - nation - education. An essay to discussing an unsolved educational issue in the European context. Hungarian Educational Research Journal. Volume 4, Issue 1, 2014. doi 10.14413/HERJ2014.02.02

wars of the Hapsburg emperors against the Ottoman Empire. The widely peaceful cohabitation of the immigrated ethnic groups lasted until World War II; but violently ended as a concomitant of the war and its outcomes.

The recent wave of migration, however, has reached much wider dimensions and is part of the world-wide economic dynamism motivating people to look for work and, in general, a 'better life' beyond the borders of their home countries. The significance of this 'modern migration' for the economic development of the continent speaks for itself and will not be discussed in the present context. Our attention is to be focused on the socio-political and educational consequences. In Western Europe this modern cross-national migration traces back to the fifties of the $20^{\text {th }}$ century and has expanded to the Central and Southeast regions since the collapse of the Communist system. On the former territory of the Soviet Union this process is paralleled by migration movements from the young Central Asian republics to the economic centres of the Russian Federation. In Western Europe the modern migration was initiated by governments and firms, for example in Western Germany. In the beginning they intended occupying workforce from less-developed countries only with the status of 'guest workers' on the base of temporary contracts with the countries of origin (mainly Southern Europe and North Africa) after the pre-arranged period of time they should return to their home countries to be replaced by 'newcomers'.

This arrangement, unrealistic though it was from its beginning, did not operate at all and was given up by opening the borders to migrant workers (now with their families) to stay in the receiving country for the time of employment and, increasingly, for their pension ages too. This trend having continued to the present day, is very likely to increase even more, since the inviting firms have changed their strategies from preferring unskilled workers to hiring technical experts (including those with university qualifications) to fill the gaps which have emerged in many economic branches. Therefore the numbers of 'foreigners' in the economic centres rapidly increase. The impacts of modern migration on the social cohesion in the countries of immigration are greatly diverse, according to the locals' readiness to accept the migrants as welcome newcomers or only to tolerate them as workforce for a fixed period. While far-sighted municipal authorities have taken measures to provide arriving migrants with accommodation all over their territories, at other towns the 'unplanned' construction of housing areas has been tolerated which has resulted in the establishment of ghetto-like housing blocks and, consequently 'parallel societies', in particular in a few suburbs of Paris and London as well as in 
Wolfgang Mitter: State - nation - education. An essay to discussing an unsolved educational issue in the European context. Hungarian Educational Research Journal. Volume 4, Issue 1, 2014. doi 10.14413/HERJ2014.02.02

the district of Kreuzberg in Berlin. This variegated trend is rapidly going on. In former periods the emergence of 'parallel societies' had turned out to have stabilizing effects, because it gave the immigrants time to make contacts with 'neighbors' of indigenous housing areas and workplaces. In this respect the immigration of Polish workers to the North of France and the Ruhr District of Germany at the end of the $19^{\text {th }}$ century can be quoted as a good example. Therefore these integration processes, though not being smooth at all; occurred without the hectic concomitants which are characteristic of their current counterparts. This time factor is not paid the attention it should need, neither in the current policies nor in public discussions.

As regards the political status of the current migrant populations, there is a fundamental difference compared to that of the 'traditional' indigenous minorities. When arriving in the country of immigration they, as a rule, are not provided with this status of fully recognized citizens, but considered just as inhabitants with temporary or permanent residence permit (though, in Germany, frequently garnished with the characterization of 'co-citizen'). In this categorization it remains open, whether the migrant, after a certain period of residence, has been offered the citizenship of his new 'home country' or retains that of his country of ancestry and birth. In some countries migrants get the chance of possessing both citizenships. In any case, the effects are varied with regard to acceptance of social and health services, and also to the chances for the migrants' children to be fully admitted to the public education systems. Apart from comparatively small numbers of private institutions offering tuition in the vernacular language, most children attend regular schools where they are taught in the official 'national language'. In Germany, for instance, the basic knowledge of German is expected to be transmitted at the stage of preschool education already. Since however, this expectation, particularly in separated living quarters, can be hardly fulfilled, one can find places with schools attended by (almost) one hundred per cent of migrant pupils leaving school with very poor knowledge of the 'national language' and consequently, few chances to be integrated in the labor market. That means they are pre -determined for a path to unemployment. It would, however, be erroneous to generalize these negative effects and to ignore the educational, social and professional advancement of a growing number of young migrants, last but not least as a consequence of promoting measures exercised by the educational authorities and, above all, by school communities or individual teachers at the grassroots. 
Wolfgang Mitter: State - nation - education. An essay to discussing an unsolved educational issue in the European context. Hungarian Educational Research Journal. Volume 4, Issue 1, 2014. doi 10.14413/HERJ2014.02.02

\section{The Way ahead: Expectations, Desires, Demands}

Our concluding deliberations should be introduced by a quotation from Elias Canetti's first volume of his noteworthy autobiographical work Die gerettete Zunge (The Saved Tongue) (Canetti 1981, cf. Mitter 2006, p. 189). Canetti, one of the prominent poets and authors of the twentieth century, was born in Russe, a town on the southern shores of the Danube, which, in the 1870s, changed its political allocation, i. e. from the Ottoman Empire to the new Principality (the later Kingdom) of Bulgaria. This is why he explains why he passed his early childhood in a multiethnic environment with various languages used in the everyday communication: Bulgarian, Turkish, Spanish (spoken in an antiquated form by Jews whose ancestors had been expelled from Spain), Greek, Armenian, Albanian and Romany, according to Canetti's own retrospect. The quoted passage deals with his reminiscences of the Balkan fairy tales which had been told to him in his early childhood:

"They are present to me in all details, but not in the language in which I had listened to them. I have listened to them in Bulgarian, but I know them in German. Perhaps this mysterious transfer is the strongest matter I have to report from my boyhood, and since the linguistic development of most children takes another course, I should say something about it.

My parents used to speak German between each other, about which I must not understand anything. To us, the children, as well as to all relatives and friends, they spoke Spanish. That was the actual colloquial language, though an antiquated Spanish; I heard it later too and have never unlearned it. The peasant girls at home only knew Bulgarian, and I may have learned it mainly while communicating to them. Though, since I never attended a Bulgarian school and left Russe at the age of six, I forgot it completely very soon.

All events of those early years took place in Spanish or Bulgarian, but they have borne them in my mind in German for the most part. Only extraordinary dramatic events, such as murder and killing, have survived in me in their Spanish wording, but in very exact and indestructible form. All the other reminiscences, that are the most, and mainly all Bulgarian, such as the fairy tales, have been retained in my mind in German.

How all that had taken place, I cannot say. I do not know, at what time, on what occasion this or that has been translated." (Canetti, 1981, pp. 15-16, my translation). 
Wolfgang Mitter: State - nation - education. An essay to discussing an unsolved educational issue in the European context. Hungarian Educational Research Journal. Volume 4, Issue 1, 2014. doi 10.14413/HERJ2014.02.02

It should be added that Canetti spent his later boyhood in Austria and Germany and later found his permanent home in England, without, however, giving up German as his literary medium. Summing up, he was a European, and, moreover, a cosmopolitan. It would be misleading nevertheless to take his linguistic biography as an example for asserting that multilingualism as a phenomenon was restricted to the intellectual elite. In this respect Canetti was a representative of the widespread pre-World War I generations to whom I referred in the second part of the present essay.

In which respect can Canetti's experiences have an advantageous impact on Europe's march into the future? He made them in his childhood in a multicultural society. It is true that the socio-political structure of his environment was far from being democratic, as regards special rights granted to socio-ethnic groups to be formally recognized by legal or administrative provisions, while the educational language was dominated, as a rule, by governments using the 'governing' (Ottoman Empire) or the 'national' language (Principality of Bulgaria). It is evident that the democratic character of the current European nation states radically differs from that type of state which had determined the people's ways of life in Canetti's early childhood. Europe as a whole, however, has inherited the multicultural and multilingual composition of its population which has distinguished the continent from its medieval times, if not even from the antiquity. However, this heritage can be made fruitful only when the Europeans are aware of the destructive effects produced by the counter-forces of particularism, nationalism and xenophobia, the more so as those forces have always used language chauvinism and the perversions of the 'national idea' as instruments for realizing their xenophobic intentions. They are likely to remain present in the foreseeable future, therefore challenging continuous efforts to me made in favor of intercultural communication and education. Even if this challenge has been increasingly adopted as such by national governments and supra- and international agencies as well by the public opinion, Europeans (as part of the global society) have to make every effort to look for effective solutions through compromise with regard to the different and changing 'environmental circumstances'. In particular the challenge includes reconciliation of the traditional concept of national heritage including educational sovereignty with the expansion of supra-national political concepts which are very likely to alter character and self-awareness of the existing nation states in the near future. It is true that in the concrete case this process will depend on the cultural attitudes and habits of both the migrants and locals, but, generally speaking, it will be an all-European trend. 
Wolfgang Mitter: State - nation - education. An essay to discussing an unsolved educational issue in the European context. Hungarian Educational Research Journal. Volume 4, Issue 1, 2014. doi 10.14413/HERJ2014.02.02

The retrospect into the past centuries of Europe teaches us that, in principle, the definition of the nation state in its congruence with one 'national language' has, in most cases, proved not to be based on real facts, but rather on the ideological concept of a narrow nationalism with utopian expectations. It is high time to recognize this concept as a wrong track and, instead, to revise it by an open and integrative re-definition that gives space for peaceful, cohabitation and co-operation within the 'wider' nation which includes equal rights to all its citizens, regardless of their cultural (including religious)and linguistic backgrounds. In such a European community - as part of the global society - nations should not only survive, but enjoy the freedom of developing their specific ways of life, including the status of the 'national language' as well as the multilingual quality of their education systems. It is true that in the reformed nation state the migrant with multicultural background has to accept the constitutional and legal norms of his new state of residence, including the acquisition of the 'national language' as the official and public idiom of communication and the state's 'educational sovereignty'. On the other hand the state should keep its distance from 'assimilating' its 'new' citizens, as concerns their wish to use their native tongues in their private lives. Moreover, their claim should be respected that provisions should be made for their children to learn their mother tongue as a second instructional medium ${ }^{3}$. In such a community all citizens should be able to bring in their local, national and supranational (in this case European) identities. This plea should not be understood as a contradiction to the principle of one language as a means of communication among all citizens. Without accepting this challenge Europe will not go ahead as a continent to be built on peace and tolerance. The contours of this target seem to be clear, but hard efforts are to be made to fill them with substantial contents.

\section{References}

Archer, M. S. (1984). Social origins of educational systems. London: Sage.

Canetti, E. (1981) Die gerettete Zunge. Geschichte einer Jugend [The saved tongue: History of a boyhood]. Frankfurt am Main: Fischer Taschenbuch Verlag.

Cowen, R. (1998). Thinking comparatively about space, education and time. An approach to the Mediterranean rim. In A. Kazamias in collaboration with M. G. Spillaine (ed.), Education and structuring of European space (pp. 61-72). Athens: Seiros Editions.

Dale, R. \& Robertson, S. I. (2002). The varying effects of regional organizations as subjects of globalization of education. Comparative Education Review, 46(1), 10-36. doi $\underline{10.1086 / 324052}$ 
Wolfgang Mitter: State - nation - education. An essay to discussing an unsolved educational issue in the European context. Hungarian Educational Research Journal. Volume 4, Issue 1, 2014. doi 10.14413/HERJ2014.02.02

Heckel, H. (1986). Schulrechtskunde [School law]. $6^{\text {th }}$ entirely revised edition by H. Avenarius in collaboration with H. Fetzer. Neuwied / Darmstadt: Luchterhand.

Mitter, W. (2004). Rise and decline of education systems: a contribution to the history of the modern state. Compare, 34(4), 351-369. doi 10.1080/0305792042000294788

Mitter, W. (2006). Language policies and language conflicts and their impacts on education systems in Europe: Retrospect and perspectives. In H. Ertl (Ed.), Crossnational attraction in education, accounts from England and Germany (pp. 183-193). Oxford-Didcot: Symposium Books

Renan, E. (1996). What is a nation? In J. Eley \& R. G. Suny (Eds.), Becoming national. $A$ reader (pp. 41-55). New York and Oxford: Oxford University Press.

Seibt, F. (1992). Natio bohemica. In H. Rothe (ed.), Deutsche in den böhmischen Ländern (pp. 29-46). Köln: Böhlau.

Trouillet, B. (1997). Das Elsass - Grenzland in Europa. Sprachen und Identitäten im Wandel [The Alsace, frontier country in EUrope. Languages and identities in change] Köln: Böhlau.

Weber, P. J. (2004). Bildungspolitik und Sprachenpluralismus in der Europäischen Union - Notwendigkeiten einer transnationalen und plurizentrischen Bildungspolitik [Educational policy and language pluralism in the European Union - necessities of transnational and pluricentrist educational policy]. Bildung und Erziehung, 57(1), pp. 525.

Wandruszka, A. \& Urbanitsch, P. (Eds.) (1980). Die Habsburgermonarchie 1848 1918. Band III: Die Völker des Reiches, 2.Teilband [The Hapsburg Empire 1818-1918, vol. III: The nations of the empire, 2nd part]. Wien: Österreichische Akademie der Wissenschaften.

\section{Postscript}

This paper is dedicated to my friend and colleague Tam s Kozma to express my great respect for his long-standing scientific work and to his diverse engagement in educational and scientific guidance and management. In particular, however, this dedication is a good opportunity for me to record our co-operation and friendship which has lasted for more than thirty years. It traces back to our first meeting in Würzburg (Bavaria) on the occasion of the $11^{\text {th }}$ Conference of the Comparative Education Society in Europe (CESE) from $3^{\text {rd }}$ to $7^{\text {th }}$ July, 1983. Since then we have had the pleasant chances to meet at various places of the globe: Budapest, Debrecen, Frankfurt am Main, Berlin, Bautzen (Saxony), Sarajevo, Atlanta and Seoul. These meetings, reinforced by frequent correspondence, were made us exchange our views on various matters of education as well as of social, political and cultural themes. Finally, I want to give my friend my warm thanks of all the hospitality I, mostly with my wife, have enjoyed in his offices and his home. I will never miss these meetings and want to give him my best wishes to his $75^{\text {th }}$ birthday: Ad multos annos! 
Wolfgang Mitter: State - nation - education. An essay to discussing an unsolved educational issue in the European context. Hungarian Educational Research Journal. Volume 4, Issue 1, 2014. doi 10.14413/HERJ2014.02.02

\footnotetext{
${ }^{1}$ This statement does not consider the historical fact that the concept of 'nation' (natio) was spread in preceding centuries too, but in other contexts, e.g. at the academic level of medieval universities ( e.g. Charles University of Prague).

${ }^{2}$ As regards the official usage of both notions at the national and international level there are no fully acknowledged standards. As a rule, the term of 'ethnic' is focused on linguistic and, in general, cultural characteristics, whereas the term of 'national' lays stress on the legal status with special regard to 'autonomy' vis-à-vis the superordinate nation state.

${ }^{3}$ In this context the further-going issue of a 'European language' is not discussed. May it suffice to note the controversial debate on the model of fundamental equality to be awarded at best to all 'official languages' of the EU's member states and the alternative preference for English as allagreed lingua franca (cf. Weber, 2004, pp. 13-16).
} 